\title{
MICROBIOLOGICAL QUALITY OF SHELLFISH AND EVALUATION OF COMPACT DRY EC FOR DETECTING TOTAL COLIFORMS AND ESCHERICHIA COLI
}

\author{
A. VÁsquez García , S.H. Gomes de SÁa, G. De Sousa Silva ${ }^{a}$, J.E. Mejia Ballesteros ${ }^{a}$, \\ E. Barbieri ${ }^{\mathrm{b}}$, R.L. Moro de Sousa ${ }^{\mathrm{a}}$, A.M. Fernandes ${ }^{\mathrm{a}}$ and M. Mitsui Kushida ${ }^{\text {a* }}$ \\ ${ }^{a}$ Faculdade de Zootecnia e Engenharia de Alimentos, Universidade de São Paulo, Av. Duque de Caxias Norte, 225, \\ 13635-900 Pirassununga, SP. Brasil \\ b Instituto de Pesca, Agência Paulista de Tecnologia dos Agronegócios - APTA, Secretaria da Agricultura e \\ Abastecimento, Governo do Estado de São Paulo. Av. Professor Wladimir Besnard, s/nº , CP 43, CEP 11990-000, \\ Cananéia, SP. Brasil
}

(Received: 9 April 2019; accepted: 30 July 2019)

\begin{abstract}
The objective of this study was to evaluate the microbiological quality of oysters and mussels grown in Cananéia, Brazil, by analysing mesophiles, psychrothophic bacteria, moulds and yeasts, Staphylococcus aureus, and Salmonella spp., and to compare the efficiency of Compact Dry EC method and the conventional method for counting of total coliforms and Escherichia coli. The microbial analysis showed that the mean values of mesophilic counts were $3.14 \pm 0.81 \log \mathrm{CFU} \mathrm{g}^{-1}$ for oysters and $3.92 \pm 0.90$ for mussels; the mean values of psychrophilic counts were $2.78 \pm 0.75 \log \mathrm{CFU} \mathrm{g}^{-1}$ for oysters and $3.22 \pm 0.75 \log \mathrm{CFU} \mathrm{g}^{-1}$ for mussels; the mean values of mould and yeast counts were $3.70 \pm 0.58 \log \mathrm{CFU} \mathrm{g}^{-1}$ for oysters and $3.33 \pm 0.81 \log \mathrm{CFU} \mathrm{g}{ }^{-1}$ for mussels. Salmonella spp. did not present positive results, and the maximal count of Staphylococcus aureus was $1.7 \log \mathrm{CFU} \mathrm{g}^{-1}$, therefore, within the limits established in the legislation. The correlation coefficients between the Compact Dry EC method and conventional method were $>0.87$ for total coliform and $E$. coli counts for both types of shellfish. The data in this study show that the Compact Dry EC method is an acceptable alternative to conventional methods for enumeration of total coliforms and E. coli in shellfish.

Keywords: Compact Dry EC, Escherichia coli, total coliforms
\end{abstract}

In 2016, the world's aquaculture production increased by $3.4 \%$, with 80 million tons of finfish, crustaceans, molluscs, other aquatic animals, and shellfish representing 17.1 million tons (FAO, 2018). This increase of seafood production through aquaculture provides a good source of high quality protein, as seafood is an important commercial crop in many parts of the world (AMAGLiani et al., 2012). Fishery products are of great importance for human nutrition and have potential health benefits (YANG et al., 2015). Some micronutrients are highlighted as, for example, vitamin D in fish oil, or the exceptional concentration of minerals as calcium, iodine, magnesium, selenium, and zinc (RITTENSCHOBER et al., 2013). In addition, shellfish provide a favourable proportion of omega- 6 and omega-3 fatty acids (MAHAFFEY et al., 2008).

Contamination of shellfish grown in coastal marine waters is a concern for global public health and food safety, since they reflect the physical-biological characteristics of the habitat, especially water quality (DumBAuLD et al., 2009). This is due to the fact that these animals, when fed, can concentrate particles present in seawater in their tissues, acting as an important vector for pathogens such as bacteria, parasites, and viruses (LimA et al., 2013; Croci et al.,

* To whom correspondence should be addressed. Phone: +55 19 35654342; e-mail: martakushida@usp.br 
2012). As they are often consumed raw or lightly cooked, shellfish have been implicated worldwide in numerous outbreaks of food poisoning by pathogenic microorganisms (WooDs et al., 2016).

In Brazil, regulation from Agência Nacional de Vigilância Sanitária (ANVISA), regarding microbiological criteria and standards establishes for in natura shellfish the maximum allowed limits for coagulase positive staphylococci as $10^{3} \mathrm{CFU} \mathrm{g}^{-1}$ and absence of Salmonella spp. in $25 \mathrm{~g}$ of product. However, there is no limit for total coliforms and E. coli, mesophiles, psychotropic bacteria, moulds and yeasts (BRAZIL, 2001). Thus, consumers should also be informed about the hygienic and sanity quality and the warning of consuming fresh food without purification treatment. Consequently, microbiological analyses are needed to identify the effects of these microorganisms on consumer health and on the environment.

Current classical methodologies for the detection of E. coli and coliforms are labour intensive, time consuming, and costly with respect to equipment and preparation of the culture medium. The Compact Dry E. coli and Coliform Count (CD-EC) plate method is the AOAC Official Method 110402 (KoDAKA et al., 2006a). This method for the detection of $E$. coli and coliforms can give result in 20-24 h. It is easy to inoculate the liquid samples at any place. Diluted samples are inoculated onto the CD-EC plate and incubated at $35{ }^{\circ} \mathrm{C}$. Evaluations of the CD-EC plate were reported in a few kinds of food (KoDAKA et al., 2006a, b; Mizuochi et al., 2016). Furthermore, to our knowledge, only one study evaluating the effectiveness of CD-EC in shellfish is available (Hosokawa \& KoDAKA, 2010).

The objective of this study was to evaluate microbiological quality of oysters and mussels grown in the Estuary Lagunar Complex of Cananéia, São Paulo, Brazil, by analysing mesophilic and psychrotrophic bacteria, moulds and yeasts, Staphylococcus aureus and Salmonella spp., and to compare the efficiency of Compact Dry Coliform (CD-EC) method and conventional method for counting total coliforms and E. coli.

\section{Materials and methods}

\subsection{Description of the sampling area}

This study was carried out on natural banks of the Estuary Lagunar Complex of Cananéia, situated between the latitudes $24^{\circ} 40^{\prime} 00^{\prime \prime}$ and $25^{\circ} 05^{\prime} 00^{\prime \prime} \mathrm{S}$ and longitudes $47^{\circ} 25^{\prime} 00^{\prime \prime}$ and $48^{\circ} 00^{\prime} 00^{\prime \prime} \mathrm{W}$, on the Southeast Coast of Brazil (Tramonte et al., 2016). This region has special relevance as an important biological reserve, contains federal and state Environmental Protected Areas, and is part of the largest continuous remnant of Atlantic Forest (UNESCO, 2010). Sample collection at the Cananéia Estuary was conducted at two sites: site one, Retiro Itapanhoapina in August 2016; site two, Resex of Mandira in October, in December 2016, and February 2017, adding up to four samplings in the experiment.

\subsection{Sampling and preparation}

Within each sampling, 15 samples of mussels (Mytella falcata) and 15 samples of oysters (Crassostrea brasiliana) were taken in the months of August, October, and December 2016 and February 2017. Each mussel sample was composed of approximately 25 units, and each oyster sample contained 10 units, being randomly chosen and then shucked. The stomach and digestive diverticula were isolated by dissection and pooled to obtain $25 \mathrm{~g}$ of tissue. A total of 120 samples, constituted by mussels $(n=60)$ and oysters $(n=60)$, were analysed. 


\subsection{Microbiological analyses}

Aliquots of $25 \mathrm{~g}$ of each sample were aseptically weighed into sterile plastic bags and homogenized with $225 \mathrm{ml}$ of $0.1 \%$ (w/v) peptone water (Himedia ${ }^{\circledR}$, Mumbai India). Decimal dilutions from dilution $10^{-1}$ were prepared in tubes containing $9.0 \mathrm{ml}$ of $0.1 \%$ peptone water. All samples were homogenized in Colworth Stomacher ${ }^{\circledR}$ Circulator and incubated in chamber BOD model 347 CD (Fanem ${ }^{\circledR}$ - São Paulo, Brazil). For the determination of total coliforms and Escherichia coli Compact Dry ${ }^{\circledR}$ EC kit (Nissui Pharmaceutical Company LTD - Ibaraki, Japan) was used with incubation at $35 \pm 2{ }^{\circ} \mathrm{C}$ for $24 \mathrm{~h}$. In this medium coliforms form blue colonies, while the colonies of $E$. coli are red. Total coliform count is the sum of both the red and blue colonies. For comparison, conventional MPN method (Most Probable Number) was used (SILva et al., 2010). Samples were diluted and cultivated in Sodium Lauryl Sulfate Broth (Himedia ${ }^{\circledR}$, Mumbai, India). The tubes with oyster and mussel samples were incubated at 35 ${ }^{\circ} \mathrm{C}$ for 24 hours. Already those who showed gas production in the pipes of Durham and/or acidified the medium (yellowish coloration) were considered positive. For confirmation of coliforms, the cultures with positive results from the previous test were inoculated into Brilliant Green Bile Broth $(2 \%)$ (Himedia ${ }^{\circledR}$, Mumbai, India), incubated at $35 \pm 1{ }^{\circ} \mathrm{C}$ for 48 hours. For E. coli, the samples were transferred to and incubated in EC Broth specific for Escherichia coli (Himedia ${ }^{\circledR}$, Mumbai, India), used as an indicator of pathogenic enteric bacteria, for an interval of 18 to 24 hours at $44.5 \pm 0.2{ }^{\circ} \mathrm{C}$. Spread plate technique was used for analysing mesophilic and psychrotrophic bacteria, moulds and yeasts (SILvA et al., 2010). For mesophilic bacteria determination the samples were incubated at $35 \pm 2{ }^{\circ} \mathrm{C}$ for $48 \mathrm{~h}$, for psychrotrophic bacteria at $7 \pm 2{ }^{\circ} \mathrm{C}$ for 10 days, for moulds and yeasts at $25 \pm 2{ }^{\circ} \mathrm{C}$ for 5 days. The determination of Staphylococcus aureus counts was performed by Compact Dry ${ }^{\circledR}$ XSA kit (Nissui Pharmaceutical Company LTD - Ibaraki, Japan), and the samples were incubated at $35 \pm 1{ }^{\circ} \mathrm{C}$ for $24 \mathrm{~h}$. For Salmonella spp. detection the BAX ${ }^{\circledR}$ kit (DuPont Qualicon Wilmington, USA) was used and the samples were incubated at $35 \pm 2{ }^{\circ} \mathrm{C}$ for $24 \mathrm{~h}$.

\subsection{Statistical analyses}

Quantitative microbiological results were reported as log CFU per gram. Means and standard deviations were calculated and subjected to analysis of variance (ANOVA) and the Tukey's test, in order to compare the variation among sampling months. $\mathrm{P}$ values $\leq 0.0001$ were considered to be significant.

\section{Results and discussion}

Table 1 shows that mesophilic bacterial count ranged from $1.97 \pm 0.32$ to $4.21 \pm 0.26$ $\log \mathrm{CFU} \mathrm{g}^{-1}$ (oysters) and $2.72 \pm 0.57$ to $5.22 \pm 0.54 \log \mathrm{CFU} \mathrm{g}^{-1}$ (mussels); with average values of $3.14 \pm 0.94$ for oysters and $3.92 \pm 1.04 \log \mathrm{CFU} \mathrm{g} \mathrm{g}^{-1}$ for mussels. LINGHAM and co-workers (2016) investigated the microbiological quality of oysters (Crassostrea virginica) and obtained values of $4.2 \log$ CFU g ${ }^{-1}$, while SALLES and co-workers (2017) obtained a density close to $5 \log$ CFU g ${ }^{-1}$ in Sarnambi (Phacoides pectinitus) species. Although there are no maximum limits for counts of deteriorating microorganisms in shellfish determined in legislation, ICMSF (1998) establishes a maximum count of $6 \log$ CFU g ${ }^{-1}$ of mesophiles in raw, chilled, or frozen fish. Therefore, the study presented results lower than the Ministry of Health's recommendation for this class of foods. 


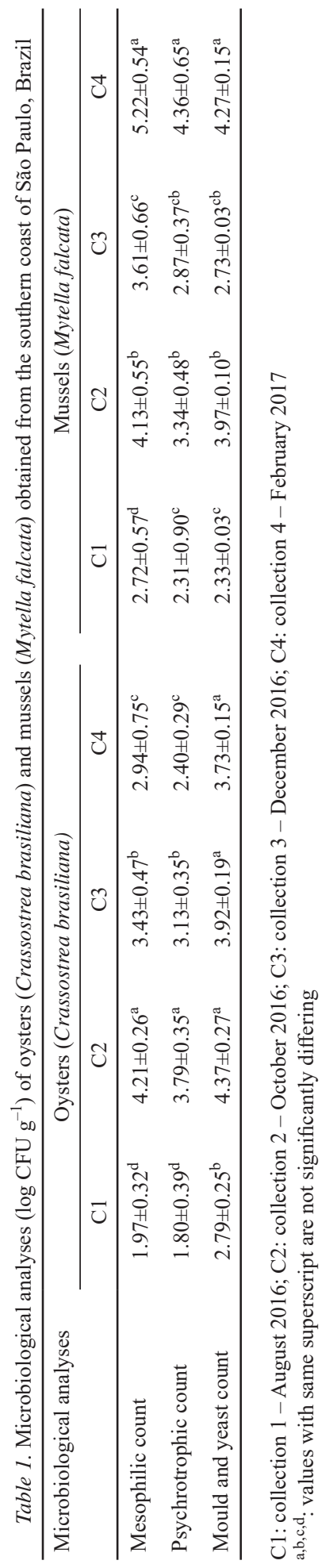


The psychrotrophic bacteria count of oyster samples varied between $1.80 \pm 0.39$ and $3.79 \pm 0.35 \log \mathrm{CFU} \mathrm{g}^{-1}$, with an average value of $2.78 \pm 0.87 \log \mathrm{CFU} \mathrm{g}^{-1}$ (Table 1), the mussel samples ranged from $2.31 \pm 0.90$ to $4.36 \pm 0.65 \log \mathrm{CFU} \mathrm{g}^{-1}$, with an average value of $3.22 \pm 0.87$ $\log$ CFU g ${ }^{-1}$. The current results were similar to those reported in the literature (CORDEIRO et al., 2007; SiLVA NETA et al., 2015).

The data presented in Table 1 show that the mould and yeast counts of oyster samples ranged from $2.79 \pm 0.25$ to $4.37 \pm 0.27 \log \mathrm{CFU} \mathrm{g}^{-1}$, with a mean value of $3.71 \pm 0.67 \mathrm{log}$ CFU g ${ }^{-1}$, and in mussel samples ranged from $2.33 \pm 0.03$ to $4.27 \pm 0.15 \log$ CFU g ${ }^{-1}$, with a mean value of $3.32 \pm 0.895 \log \mathrm{CFU} \mathrm{g}^{-1}$. The present results are not similar to that recorded by MOHAMMED and co-workers (2017), who investigated the microbiological quality of 100 samples of retailed marine fish and shellfish (sardine, mullet, crab, shrimp) collected from different fish markets at Alexandria province, with mean values of $6.8 \log \mathrm{CFU} \mathrm{g}^{-1}$ for mould and yeast counts.

The maximum count of $S$. aureus was $1.7 \log \mathrm{CFU} \mathrm{g} \mathrm{g}^{-1}$, and $77.5 \%$ of the samples presented a negative result for this microorganism. The overall mean count found for this analysis was the lowest among microorganisms evaluated in this study for all collection points throughout the study period, meeting the requirements for $S$. aureus in legislation of $2.7 \log$ CFU g ${ }^{-1}$ (BRAZIL, 2001). Similar results were reported in the State of São Paulo (GALVÃo et al., 2006), Santa Catarina (Lima et al., 2013), and Pará (SALLes et al., 2017), with all evaluated shellfish samples within the limits of Brazilian legislation.

No samples showed contamination by Salmonella spp. The same results were reported by Pereira and co-workers (2006) and Montanhini and Montanhini Neto (2015), who evaluated oysters of the State of Santa Catarina and Paraná, respectively.

The Compact Dry ${ }^{\circledR}$ (CD-EC) method was compared with conventional method (CM) using 120 samples of shellfish in order to evaluate the performance of the Compact Dry ${ }^{\circledR}$ method. Regression analyses of 60 oyster samples and 60 mussel samples on CD-EC versus $\mathrm{CM}$ for total coliforms are shown in Figure 1. The scatter plot and regression analysis shows a positive correlation between the CD-EC method and CM for total coliforms in mussel samples (Fig. 1A).

A

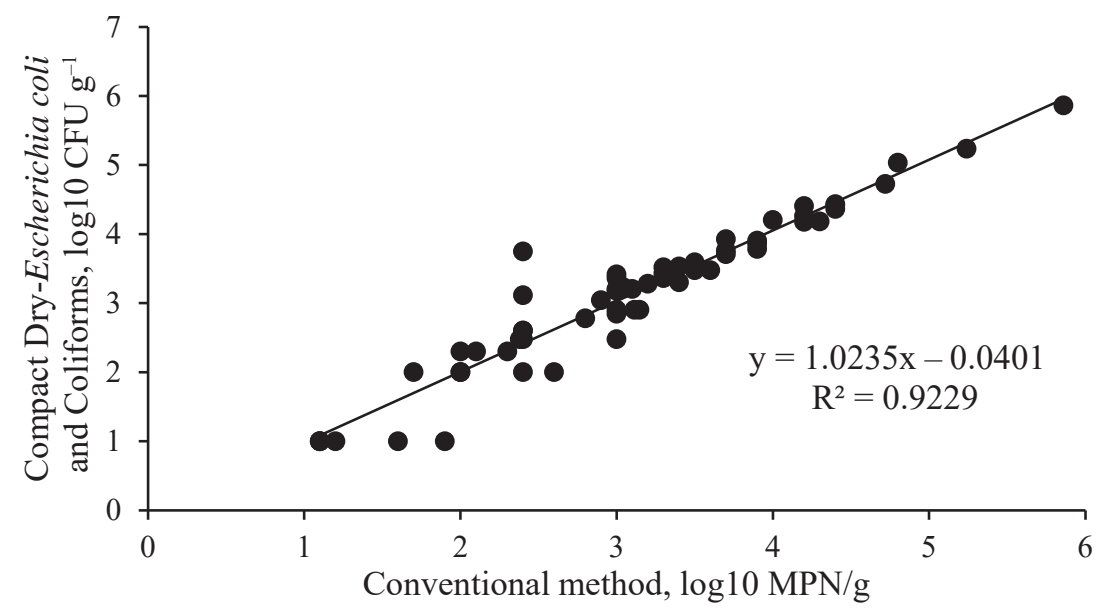

Fig. 1. Dispersion of total coliforms data in samples, obtained by conventional method (CM) (x) and with Compact Dry ${ }^{\circledR}$ method (CD-EC) (y). A: mussels; B: oysters 


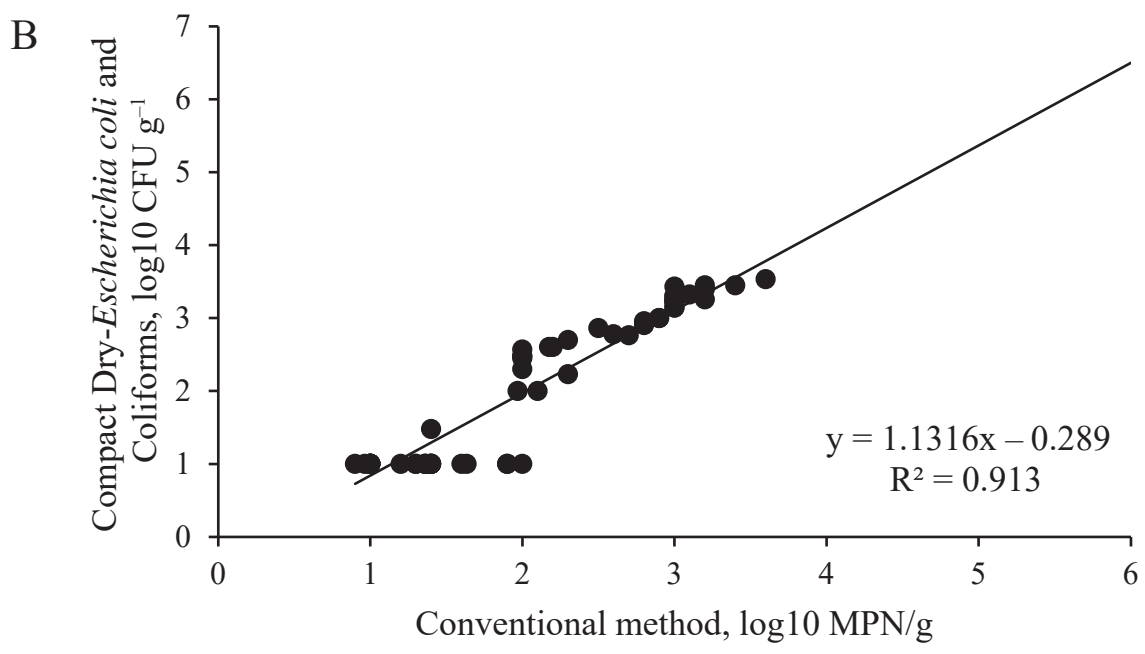

Fig. 1 continued

Figure 1B shows the dispersion of total coliforms for oyster samples with a correlation coefficient of 0.91 , a slope of 1.13 , and an intercept of 0.29 , indicating a linear relationship between the two methods. HosoKAwA and KoDAKA (2010) evaluated CD-EC method as an alternative to CM for total coliforms count in shellfish, obtaining a correlation of 0.88 .

According to Table 2, the correlation parameters between the CD-EC method and conventional method for the total coliform data of the oysters and mussels showed correlation greater than 0.90 .

Table 2. Correlation parameters for total coliform and E. coli counts from oysters and mussels obtained by CM $(\log 10 \mathrm{MPN} / \mathrm{g})$ and by CD-EC methods $\left(\log 10 \mathrm{CFU} \mathrm{g} \mathrm{g}^{-1}\right)$

\begin{tabular}{llllclc}
\hline Samples & Group & $\mathrm{n}$ & $\mathrm{R}^{2}$ & Equation & $\mathrm{a}$ & $\mathrm{b}$ \\
\hline Oysters (Crassostrea & Total coliforms & 60 & 0.91 & $\mathrm{y}=1.10 \mathrm{X}-0.29$ & 1.10 & 0.29 \\
brasiliana) & Escherichia coli & 60 & 0.87 & $\mathrm{y}=1.03 \mathrm{X}+0.01$ & 1.03 & 0.01 \\
Mussels (Mytella & Total coliforms & 60 & 0.93 & $\mathrm{y}=1.03 \mathrm{X}-0.04$ & 1.03 & 0.04 \\
falcata) & Escherichia coli & 60 & 0.93 & $\mathrm{y}=0.88 \mathrm{X}+0.37$ & 0.88 & 0.37 \\
\hline
\end{tabular}

The CD-EC has been used as an alternative method for the enumeration of these microorganisms, reaching international acceptance due to its viability in the execution and the reduction of the time in obtaining results. MizUOCHI and co-workers (2016) obtained a correlation index $>0.92$ and concluded that CD-EC method is a valid alternative to the enumeration of $E$. coli and total coliforms in cooked chicken, prewashed bagged shredded iceberg lettuce, frozen cod filets, instant nonfat dry milk powder, and pasteurized milk compared to ISO 4832:2006. 


\section{Conclusions}

The mesophilic and psychrotrophic baterium counts presented lower results than those obtained by CORDEIRO and co-workers, 2007 and SILVA and co-workers, 2015, fulfilling the recommendation of the Ministry of Health for this class of foods. The mould and yeast counts were not similar to those recorded by MoHAMMED and co-workers, 2017). Oysters and mussels from the Cananéia region of the coast of São Paulo did not present Salmonella spp. nor significant amounts of Staphylococcus aureus, thus remaining within the limits provided in the legislation. A good correlation for analyses of total coliforms and Escherichia coli in shellfish was proved for the conventional and Compact Dry EC methods.

The authors would like to thank CAPES (Coordenação de Aperfeiçoamento de Pessoal de Nível Superior) for doctoral scholarship.

\section{References}

Amagliani, G., Brandi, G. \& Schiavano, G.F. (2012): Incidence and role of Salmonella in seafood safety. Food Res. Int., 45, 780-788.

BRAZIL (2001): Regulamento técnico sobre padrões microbiológicos para alimentos (Technical regulation on microbiological standards for foods). Resolution of the College Board No. 12, from January 2nd, 2001, Brasília: Ministry of Health, National Health Surveillance Agency.

Cordeiro, D., Guimarães Lopes, T.G., Oetterer, M., Porto, E. \& Galvão, J.A. (2007): Qualidade do mexilhão Perna perna submetido ao processo combinado de cocção, congelamento e armazenamento. CEPPA Bulletin, 25, 165-179.

Croci, L., Suffredini, E., Di Pasquale, S. \& Cozzi, L. (2012): Detection of norovirus and feline calicivirus in spiked molluscs subjected to heat treatments. Food Control, 25, 17-22.

Dumbauld, B.R., Ruesink, J.L. \& Rumrill, S.S. (2009): The ecological role of bivalve shellfish aquaculture in the estuarine environment: A review with application to oyster and clam culture in West Coast (USA) estuaries. Aquaculture, 290, 196-223.

FAO (2018): The state of world fisheries and aquaculture 2018 - Meeting the sustainable development goals. Rome. Available at: http://www.fao.org/3/i9540en/i9540en.pdf (last accessed 30 July 2019), p. 5.

Galvão, J.A., Furlan, E.F., Salán, E.O., Porto, E. \& Oetterer, M. (2006): Características físico-químicas e microbiológicas (Staphylococcus aureus e Bacillus cereus) da água e dos mexilhões cultivados na região de Ubatuba, SP. Cienc. Agrotec., 30, 1124-1129.

Hosokawa, S. \& Kodaka, H. (2010): Efficacy of Compact Dry EC for coliform detection in seafood. Jpn. J. Food Microbiol., 27, 80-85.

Kodaka, H., Mizuochi, S. Teramura, H. \& Nirazuka, T. (2006a): Comparison of the Compact Dry EC with the Most Probable Number method (AOAC official method 966.24) for enumeration of Escherichia coli and coliform bacteria in raw meats: Performance-Tested Method ${ }^{\mathrm{SM}} 110402$. J. AOAC Int., 89, 100-114.

Kodaka, H., Teramura, H., Nirazuka, T. \& Mizuochi, S. (2006b): Comparison of the Compact Dry CF with the Most Probable Number method (AOAC official method 966.24) for enumeration of coliform bacteria in raw meats: Performance-Tested Method ${ }^{\mathrm{SM}} 110402$. J. AOAC Int., 89, 115-126.

ICMSF (1998): Microorganisms in foods. Sampling for microbiological analysis: Principles and specific applications. 2. ed. Londres: Blackwell Scientific Publications. pp. 181-193.

ISO (2006): Microbiology of food and animal feeding stuffs - Horizontal method for the enumeration of coliforms - Colony-count technique, ISO 4832:2006, https://www.iso.org/standard/38282.html (accessed in 2018).

Lima, M., Melo, M.C.L. \& Monteiro, A.R. (2013): Evaluation of the processing of Perna perna mussels: the influence of water quality involved in the cooling operations in the physico-chemical and microbiological characteristics of the product. J. Sci. Food Agr., 93, 3322-3329. 
Lingham, T., Ye, M., Chen, H., Chintapenta, L.K., Handy, E., Zhao, J., Wu, C. \& Ozbay, G. (2016): Effects of high hydrostatic pressure on the physical, microbial, and chemical attributes of oysters (Crassostrea virginica). J. Food Sci., 81, 1158-1166.

Mahaffey, K.R., Clickner, R.P. \& JefFries, R.A. (2008): Methylmercury and omega-3 fatty acids: Co-occurrence of dietary sources with emphasis on fish and shellfish. Environ. Res., 107, 20-29.

Mizuochi, S., Nelson, M., Baylis, C., Green, B., Jewell, K., ... \& Fernandez, M.C. (2016): Matrix extension study: Validation of the Compact Dry EC method for enumeration of Escherichia coli and non-E. coli coliform bacteria in selected foods. J. AOAC Int., 99, 451-460.

Mohammed, A.E., Abdallah, H.A., El Hafez, A.E.M.A., Amin, A. \& Mousa, M.M. (2017): Quality assessment of some retailed marine fish and shellfish in Alexandria province. AJVS, 52, 166-172.

Montanhini, M.T.M. \& Montanhini Neto, R. (2015): Microbiological quality assessment for oysters produced and traded in Paraná, Brazil. Acta Alimentaria, 44, 420-426.

Pereira, M.A., Nunes, M.M., Nuernberg, L., Schulz, D. \& Batista, C.R.V. (2006): Microbiological quality of oysters (Crassostrea gigas) produced and commercialized in the coastal region of Florianópolis - Brazil. Braz. J. Microbiol, 37, 159-163.

Rittenschober, D., NowaK, V. \& Charrondiere, U.R. (2013): Review of availability of food composition data for fish and shellfish. Food Chem., 141, 4303-4310.

Salles, P.B.D., Macedo, Y.B. \& Figueiredo, E.L. (2017): Caracterização físico-química e microbiológica da carne do molusco Bivalve Sarnambi (Phacoides pectinitus) coletado nas praias em Algodoal e Salinópolis, no Pará. R. Bras. Tecnol. Agroindustr., 11, 2245-2261.

Silva, N., Junqueira, V.C.A., Silveira, N.F.A., Taniwaki, M.H., Santos, R.F.S. \& Gomes, R.A.R. (2010): Manual de métodos de análise microbiológica de alimentos e água (Manual of methods for microbiological analysis of food and water). São Paulo: Editora Varela, 632 pages.

Silva Neta, M.T., Maciel, B.M., Lopes, A.T.S., Marques, E.L.S., Rezende, R.P. \& Boehs, G. (2015): Microbiological quality and bacterial diversity of the tropical oyster Crassostrea rhizophorae in a monitored farming system and from natural stocks. Genet. Mol. Res., 14, 15754-15768.

Tramonte, K.M., Figueira, R.C.L., Ferreira, P.A.L., Ribeiro, A.P., Batista, M.F. \& Mahiques, M.M. (2016): Environmental availability of potentially toxic elements in estuarine sediments of the Cananéia-Iguape coastal system, Southeastern Brazil. Mar. Pollut. Bull., 103, 260-269.

UNESCO (2010): Atlantic forest reserves. Available at: https://whc.unesco.org/en/list/893/ (last accessed: 10 March 2018).

Woods, J.W., Calci, K.R., Marchant-Tambone, J.G. \& Burkhardt, W. (2016): Detection and molecular characterization of norovirus from oysters implicated in outbreaks in the US. Food Microbiol., 59, 76-84.

Yang, X., Wu, Q., Zhang, J., Huang, J., Chen, L., ... \& CAI, S. (2015): Prevalence, enumeration, and characterization of Salmonella isolated from aquatic food products from retail markets in China. Food Control, 57, 308-813. 